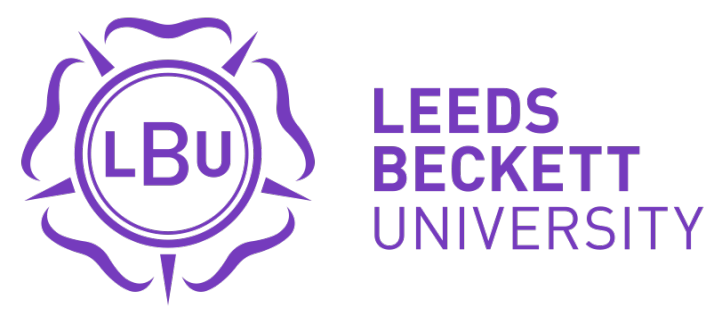

Citation:

Allen, HA and Hull, JH and O'Hara, JP and Dickinson, JW and Price, OJ (2019) P17 Dietary nitrate supplementation increases fractional exhaled nitric oxide : implications for the assessment of airway health in athletes. In: British Thoracic Society Winter Meeting 2019, 4 to 6 December 2019, QEII Centre, Broad Sanctuary, Westminster, London SW1P 3EE. DOI: https://doi.org/10.1136/thorax2019-btsabstracts2019.160

Link to Leeds Beckett Repository record:

https://eprints.leedsbeckett.ac.uk/id/eprint/6468/

Document Version:

Conference or Workshop Item (Accepted Version)

Creative Commons: Attribution-Noncommercial 4.0

The aim of the Leeds Beckett Repository is to provide open access to our research, as required by funder policies and permitted by publishers and copyright law.

The Leeds Beckett repository holds a wide range of publications, each of which has been checked for copyright and the relevant embargo period has been applied by the Research Services team.

We operate on a standard take-down policy. If you are the author or publisher of an output and you would like it removed from the repository, please contact us and we will investigate on a case-by-case basis.

Each thesis in the repository has been cleared where necessary by the author for third party copyright. If you would like a thesis to be removed from the repository or believe there is an issue with copyright, please contact us on openaccess@leedsbeckett.ac.uk and we will investigate on a case-by-case basis. 


\title{
DIETARY NITRATE SUPPLEMENTATION INCREASES FRACTIONAL EXHALED NITRIC OXIDE: IMPLICATIONS FOR THE ASSESSMENT OF AIRWAY HEALTH IN ATHLETES
}

\author{
Hayden Allen ${ }^{1}$, James H. Hull ${ }^{2}$, John P. O'Hara ${ }^{1}$, John W. Dickinson ${ }^{3}$, Oliver J. Price ${ }^{1}$ \\ ${ }^{1}$ Carnegie School of Sport, Leeds Beckett University, Leeds, United Kingdom (UK); ${ }^{2}$ Department of Respiratory \\ Medicine, Royal Brompton Hospital, London, UK; ${ }^{3}$ Sports Therapy, Physical Activity and Health Research Group, School \\ of Sport and Exercise Sciences, University of Kent, Chatham Maritime, UK
}

Background: Fractional exhaled nitric oxide (FeNO) is a simple tool that has an established role in the assessment of airway inflammation in athletes. Specifically, FeNO provides information concerning asthma phenotypes, aetiology of respiratory symptoms, response to anti-inflammatory agents, course of disease and adherence to medication. It is recognised that FeNO can be influenced by a variety of external factors (e.g. atopic status, exercise, respiratory tract infection), however, there remains limited research concerning the impact of dietary nitrate ingestion. The primary aim of this study was therefore to evaluate the effect of acute dietary nitrate supplementation on FeNO and resting pulmonary function parameters.

Method: The study was conducted as a randomised double-blind placebo-controlled trial. Thirty male endurance trained athletes (age: $28 \pm 6 \mathrm{yrs}$; BMI: $23 \pm 2 \mathrm{~kg} \cdot \mathrm{m}^{-2}$ ) free from cardio-respiratory and metabolic disease, and stable at time of study entry (i.e. entirely asymptomatic without recent respiratory tract infection) attended the laboratory on two separate occasions. On arrival to the laboratory, athletes consumed either $140 \mathrm{ml}$ nitrate-rich beetroot juice $(15.2 \mathrm{mmol}$ nitrate) (NIT) or nitrate-depleted beetroot juice ( $0 \mathrm{mmol}$ nitrate) (PLA). In accordance with international guidelines all athletes performed resting FeNO and forced spirometry (2.5hrs post ingestion). Airway inflammation was evaluated using established FeNO thresholds: (intermediate [ $\geq 25 \mathrm{ppb}]$ and high [ $>50 \mathrm{ppb}]$ ).

Results: All athletes demonstrated normal baseline lung function ( $\mathrm{FEV}_{1} \%$ predicted $>80 \%$ ). A three-fold rise in resting FeNO was observed following NIT (median [IQR]): 32ppb [37] in comparison to PLA: 10ppb [12] $(P<0.001)$. Twenty-two athletes (73\%) presented with raised FeNO following NIT (intermediate: $n=13$; high: $n=9$ ) in comparison to four athletes (13\%) following PLA (intermediate: $n=2 ;$ high: $n=2$ ). Despite this, no difference was observed in any pulmonary function parameters between visits $(P>0.05)$.

Conclusion: Dietary nitrate ingestion should be considered when employing FeNO for the assessment of airway health in athletes. Our findings have implications concerning the decision to initiate or modify inhaler therapy. Further research is therefore required to determine the impact of chronic dietary nitrate ingestion 
BTS 2019

on pulmonary function and bronchoprovocation testing in athletes with pre-existing asthma and/or exerciseinduced bronchoconstriction. 